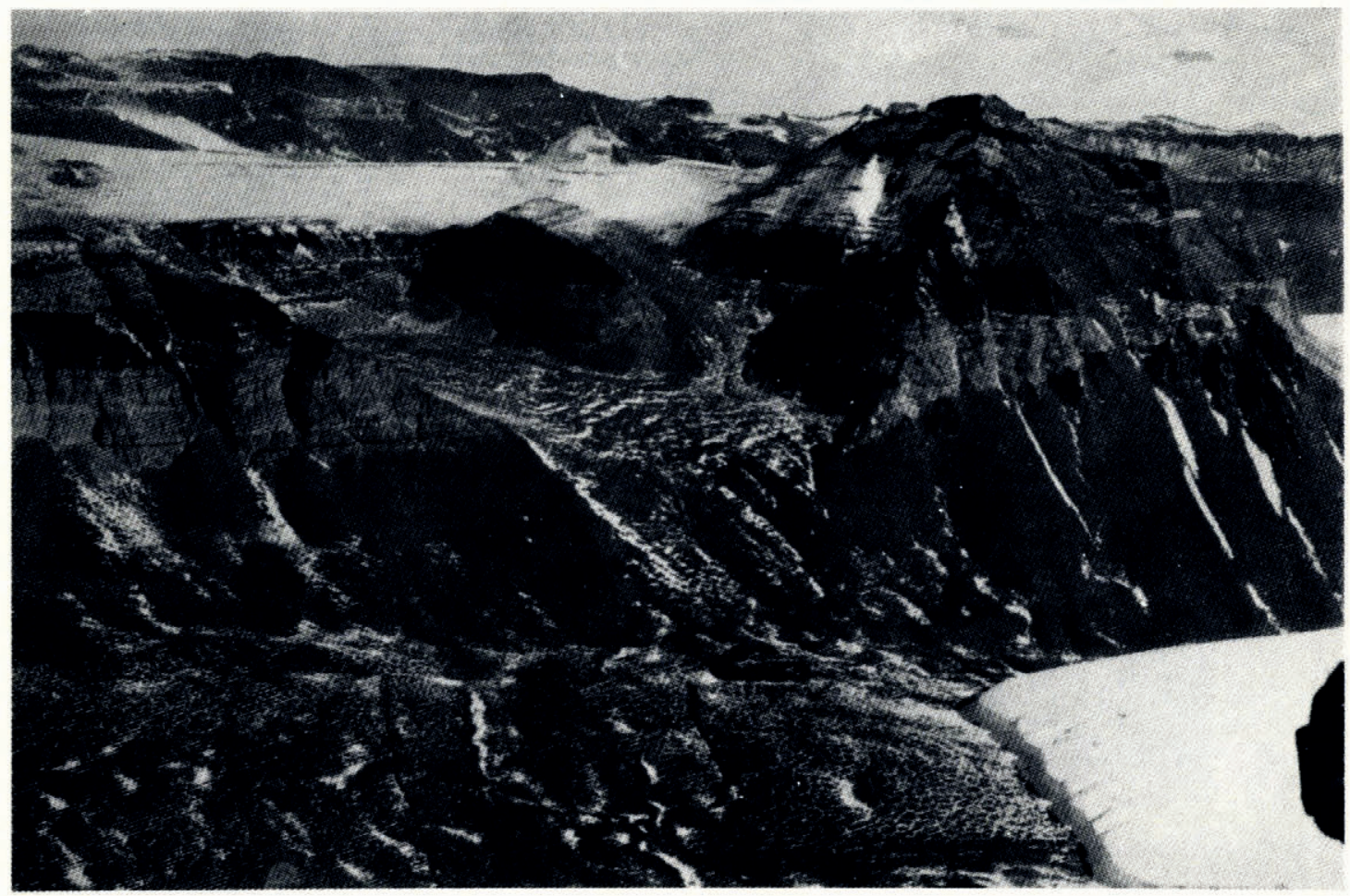

Fig. I. Terminal moraines deposited on the floor of a dry valley on the west side of Beacon Height West by a lobe of the Taylor Glacier, Victoria Land, Antarctica. The ice cliff at the terminal face of the glacier lobe is $40 \mathrm{ft}$. to $70 \mathrm{ft}$. (I2 to $21 \mathrm{~m}$.) high and a small moraine is forming at the foot of it. The névé of the Taylor Glacier merges with the South Polar Plateau in the distance. On the far side of the dry valley Pyramid Mountain and adjacent ridges consist of Beacon Sandstone intruded by Ferrar Dolerite sills and feeders. Granitic erratics occur to about $1,750 \mathrm{ft}$. (530 $\mathrm{m}$.) above the floor of the dry valley, and were deposited during one or more Quaternary glacial maxima

The Editor,

\title{
GORRESPONDENGE
}

\section{The Fournal of Glaciology}

SIR, $\quad$ Recent moraines of a lobe of the Taylor Glacier, Victoria Land, Antarctica

The task of measuring directly changes in the regimen and balance of the Antarciic Ice Sheet on the South Polar Plateau west of the mountains of Victoria Land is not easy for a number of reasons. These include the relative inaccessibility of the Plateau and the difficulty of recognizing annual layers in snow pits and drill holes. Other evidence of recent changes has been sought, therefore, by several workers.

In January 1959 the writers were taken in a United States Navy helicopter from McMurdo Sound to the upper Taylor Glacier to establish survey stations and to examine the type section through the Beacon Sandstone in the peaks called Beacon Heights by Ferrar. ${ }^{{ }}$The Taylor Glacier flows directly from the Plateau and from part of its southern lateral margin a lobe flows into an unnamed dry valley (lat. $77^{\circ} 47^{\prime} \mathrm{S}$., long. $162^{\circ} 20^{\prime}$ E.) on the west side of Beacon Heights (Fig. I, above).* The glacier is clearly very sluggish, and consequently at its margin there is a steep ice cliff formed by radiation of heat in summer from neighbouring bare rock areas. Examination of the ice cliffs shows that the glacier

* Dr. Harrington points out that this photograph is also of historical interest; it shows a part of the region traversed by Captain Scott's two seamen on the first journey to the South Polar plateau during the National Antarctic Expedition of 1901-04- - Ed. 
contains very little morainic material, although scattered boulders occur on the glacier surface for $200 \mathrm{~m}$. or more from its lateral margin as a result of wind ablation.

A small moraine is forming at the present edge of the ice, and retreat of the terminal face of the dry valley lobe is recorded by another four, or possibly five, stranded terminal moraines (Fig. I). These are distinct, but are small because the glacier is slow and contains very little moraine. Vague traces of even older terminal moraines in the same series are visible on the floor of the dry valley further up-stream from the glacier snout.

There is no direct evidence of the age of the moraines but they have a recent appearance, and it is tempting to correlate the latest three of them with moraines occurring in the temperate latitudes in both hemispheres, such as the 1820,1850 and 1890 moraines of the European Alps, and three correlative moraines of the Hooker Glacier in New Zealand. ${ }^{2}, 3$ It has been questioned whether climatic changes occur simultaneously and in the same direction towards greater coolness or warmth in the Antarctic and in temperate regions. It has been suggested also that warming of the Antarctic leads to increased snowfall and expansion of glaciers there. If the Taylor Glacier moraines are correlatives of the European moraines, then the implications follow, first that recent climatic changes have been contemporaneous and in the same direction (towards warming) in both regions, and secondly that warming of the Antarctic, at least in the Taylor Glacier region, leads to contraction of glaciers. Until the Taylor Glacier moraines can be dated by some means these implications must be treated with reserve, but they do not conflict with independent evidence provided by cores of Ross Sea sediments, ${ }^{4}$ by a radiocarbon date, ${ }^{5}$ and by measurement of the temperature profile in a deep drill hole in ice at Byrd Station. ${ }^{6}$

The Taylor Glacier apparently drains a large area of the Plateau, but the retreat of its dry-valley lobe has been relatively very small. This suggests that associated changes in the level of the Plateau have probably been so small that they may not be detected by observation of the lower limit of lichen colonization of nunataks.

I6 July 1959

H. J. Harrington,
Geology Department,
University of New Engiand,
Armidale, N.S.W.,
Australia

I. G. Speden,
Geological Survey,
Box 368 ,
Lower Hutt,
New Zealand

\section{REFERENGES}

I. Ferrar, H. T. Report on the field-geology of the region explored during the "Discovery" Antarctic Expedition, r 90I-04. (In Geology. London, British Museum (Nat. Hist.), 1907. (National Antarctic Expedition, r9or-
r 904 . Natural History, Vol. I.))

2. Harrington, H. J. Glacier wasting and retreat in the Southern Alps of New Zealand. Journal of Glaciology,
Vol. 2, No. 12, 1952, p. 140-45.

3. McKellar, I. C. Stranded moraines of the Hooker and Mueller Glaciers. New Zealand Journal of Science and Technology, Sect. B, Vol. 37, No. 2, 1955, p. $221-23$. 4. Hough, J. L. Sediment distribution in the Southern Oceans around Antarctica. Fournal of Sedimentary Petrology,
Vol. 26, No. 4, I 956 , p. 301-06.

5. Harrington, H. J., and McKellar, I. C. A radiocarbon date for penguin colonization of Cape Hallett, Antarctica. New Zealand Journal of Geology and Geophysics, Vol. 1, No. 3, 1958, p. 571-76.

6. Wexler, H. Geothermal heat and glacial growth. Journal of Glaciology, Vol. 3, No. 25, r959, p. 420-25.

SIR,

\section{Geothermal heat and glacial growth}

I can only admire the article of Dr. H. Wexler in the March 1959 number, ${ }^{1}$ and the novel application of his equations. But it seems to me that, in addition to the $31 \cdot 6 \mathrm{cal} . \mathrm{cm} \cdot .^{-2} \mathrm{yr} .^{-1}$ geothermal heat flux which he uses for $F_{\mathrm{o}}$ in these equations, there should also be added the heat of friction if the glacier is in a steady state yet accumulating $30 \mathrm{~cm}$. of ice per annum (if it were motionless, the steady state could not be). Nor is the heat of friction difficult to compute- $30 \mathrm{~cm} .(25 \mathrm{~g}$.) of ice added over the length of any glacier $3,000 \mathrm{~m}$. thick is the equivalent of $25 \mathrm{~g}$. falling $3,000 \mathrm{~m}$. in one year over each square centimeter of surface. This gives about $7 \times 10^{9} \mathrm{ergs}$, or $150 \mathrm{cal} . \mathrm{cm}^{-2} \mathrm{yr} .^{-\mathrm{r}}$, five times the geothermal heat flux! No appreciable amount of this work could have been syphoned off as kinetic energy of the moving glacier before conversion into heat; even at a velocity of $100 \mathrm{~m} . \mathrm{yr} .^{-1}$ for the glacier, the kinetic energy of that ice column would be quite negligibly small.

Also as regards the value of $K$, the thermal conductivity of the glacier ice, which Wexler takes as 